\title{
SIFAT FISIK DAN KANDUNGAN GIZI BUAH KANCING BAJU, KETIPAN, DAN TAMANG HUTAN DI KALIMANTAN BARAT
}

\author{
Dinda Anindya ${ }^{1}$, Entin Daningsih ${ }^{2}$, Titin $^{3}$ \\ ${ }^{1,2,3}$ Program Studi Pendidikan Biologi, FKIP, Universitas Tanjungpura \\ Jalan Prof. Dr. H. Hadari Nawawi Pontianak 78124 \\ e-mail: dindaanindyaa@gmail.com
}

\begin{abstract}
Abstrak
Kerusakan pada hutan menyebabkan keanekaragaman buah-buahan hutan menjadi langka. Penelitian dilakukan untuk mengetahui sifat fisik dan kandungan gizi pada buah kancing baju, ketipan, dan tamang hutan. Teknik pengambilan sampel yaitu random sampling. Penelitian pertama berbentuk deskriptif dengan mengamati sifat fisik pada buah. Karakter yang diamati adalah warna kulit muda, warna kulit matang, permukaan kulit, warna daging, warna biji, ukuran buah, bentuk buah, jumlah biji, ukuran biji, tekstur daging buah, rasa daging buah, dan aroma buah. Bentuk penelitian kedua berupa eksperimen dengan menguji kandungan gizi pada buah dengan model RAL. Hasil penelitian yaitu sifat fisik menunjukkan perbedaan pada setiap buah sedangkan hasil analisis kandungan gizi menunjukkan bahwa semua variabel yang diukur yaitu kandungan karbohidrat total, glukosa, fruktosa, sukrosa, air, lemak, protein, serat kasar, abu, dan vitamin $\mathrm{C}$ memiliki perbedaan yang signifikan antar buah.
\end{abstract}

Kata Kunci: sifat fisik, kandungan gizi, kancing baju, ketipan, tamang hutan.

\begin{abstract}
Damage to the forest causes the diversity of forest fruits to become scarce. This research was conducted to find out the physical characteristics and nutrient content of the fruit 'kancing baju', 'ketipan', and 'tamang hutan'. The samples were collected with random sampling technique. The first study was descriptive by observing the physical properties of the fruits. The observed characters were the color of young skin, mature skin color, skin surface, meat color, seed color, fruit size, fruit shape, number of seeds, seed size, fruit meat texture, fruit meat flavour and fruit aroma. The second form of study was experimental design using CRD model by testing the nutrient content in the fruits. The result of physical properties shows the difference in each fruit while the result of nutrient analysis shows that all variables namely total carbohydrate content, glucose, fructose, sucrose, water, fat, protein, crude fiber, ash, and vitamin C had significant difference among the fruits.
\end{abstract}

Keywords: physical properties, nutritional content, kancing baju, ketipan, tamang hutan.

\section{PENDAHULUAN}

Kalimantan Barat merupakan daerah khatulistiwa dengan banyaknya kekayaan tumbuhan yang sangat melimpah. Diantaranya keanekaragaman dari jenis buah-buahan, tetapi tumbuhan di hutan semakin berkurang karena ditebang untuk dijadikan lahan sawit. Hal tersebut dapat menyebabkan kerusakan yang 
mengakibatkan keanekaragaman buah-buahan terancam punah dan memberikan dampak buah-buahan menjadi langka.

Buah adalah salah satu jenis makanan yang memiliki kandungan gizi, vitamin, dan mineral yang sangat baik bagi tubuh. Salah satu keanekaragaman dari jenis buah-buahan yang ditemukan di hutan Desa Serimbu, Kecamatan Air Besar, Kabupaten Landak, Kalimantan Barat adalah buah kancing baju (Etlingera elatior), ketipan (Lansium parasiticum), dan tamang hutan (Ardisia pterocaulis Miq).

Kandungan gizi (nutrisi) adalah setiap zat yang dicerna, diserap, dan digunakan untuk mendorong kelangsungan kerja tubuh. Nutrien dapat dipilah menjadi protein, lemak, mineral, vitamin, serat, dan air (Beck, 2011). Gizi adalah senyawa kimia yang mutlak diperlukan oleh tubuh. Jika tubuh kekurangan gizi maka keseimbangan fungsi organ tubuh akan terganggu. Kandungan gizi dapat ditemukan pada buah-buahan, seperti buah kancing baju (Etlingera elatior), ketipan (Lansium parasiticum), dan tamang hutan (Ardisia pterocaulis Miq) .

Pengamatan terhadap sifat fisik bertujuan agar masyarakat dapat mengetahui karakteristik pada buah. Setelah dilakukan pengamatan sifat fisik, selanjutnya pengujian terhadap kandungan gizi pada buah yang bertujuan agar dapat memberikan informasi kepada masyarakat luas akan potensi buah kancing baju, ketipan, dan tamang hutan di Kalimantan Barat, serta dapat memberikan kesadaran untuk dilakukannya upaya agar tumbuhan yang langka tersebut dapat dilestarikan dan dibudidayakan.

\section{METODE}

Penelitian mengenai sifat fisik buah merupakan penelitian deskriptif. Sampel yang diamati adalah buah kancing baju (Etlingera elatior), ketipan (Lansium parasiticum), dan tamang hutan (Ardisia pterocaulis Miq). Buah yang diambil merupakan buah yang dapat dimakan secara langsung dan diamati sifat fisik buah yaitu warna kulit muda, warna kulit matang, permukaan kulit, warna daging, warna biji, ukuran buah, bentuk buah, jumlah biji, ukuran biji, tekstur 
daging buah, rasa daging buah, dan aroma buah. Pengamatan tingkat kematangan buah diukur menggunakan $\mathrm{pH}$ indikator universal dan refractometer.

Penelitian uji kandungan gizi menggunakan Rancangan Acak Lengkap (RAL) dengan tiga perlakuan dan sembilan replikasi. Populasi penelitian adalah buah kancing baju, ketipan, dan tamang hutan di Kabupaten Landak. Sampel penelitian adalah buah kancing baju, ketipan, dan tamang hutan dari masingmasing buah dipilih tiga pohon. Untuk setiap pohon diambil minimal tiga buah untuk mencapai berat 168 gram.

Alat yang digunakan dalam penelitian yaitu blender, pisau, neraca analitik, neraca ohaus, kaca arloji, cawan porselin, gelas kimia $250 \mathrm{ml}$, pipet tetes, buret, klem buret, gelas kimia $100 \mathrm{ml}$, penjepit tabung, corong, bunsen, korek api, batang pengaduk, spektrofotometer, cuvet (tabung spektrofotometer), sentrifug, tabung sentrifug, tabung reaksi, rak tabung reaksi, gelas ukur, labu takar, stopwatch, tabung ekstraksi soxhlet, thimble, kondensor, soxhlet, staples, penangas air, batang statis, penjepitnya, gunting jepit, oven, desikator, erlenmeyer $250 \mathrm{ml}$, water bath, hot plate, kaca penutup tabung, krus gooch $20 \mathrm{ml}$, tanur, pH indikator universal dan refractometer.

Bahan yang digunakan dalam penelitian secara keseluruhan 168 gram daging buah kancing baju, ketipan, dan tamang hutan untuk setiap jenis buah. Selanjutnya, bahan dibagi berdasarkan uji kuantitatif yang dilakukan di mana 150 gram bahan dihaluskan, dan 18 gram bahan tidak dihaluskan, akuades, benedict, dan kertas saring, amido black, petroleum ether, alumunium foil, larutan amilum $1 \%$, dan yodium $0,01 \mathrm{~N}$, larutan $\mathrm{H}_{2} \mathrm{SO}_{4} 0,2 \mathrm{~N}$, larutan $\mathrm{NaOH} 0,2 \mathrm{~N}$, larutan $\mathrm{K}_{2} \mathrm{SO}_{4}$, alkohol $96 \%$.

Tahapan dalam pelaksanaan uji kandungan gizi yang pertama preparasi bahan, untuk uji karbohidrat menggunakan metode benedict kuantitatif (Plummer, 1971), dan uji lainnya (Sudarmadji, 1997) yaitu uji protein menggunakan cara spektrofotometri, uji lemak menggunakan soxhlet, uji vitamin C menggunakan cara titrasi yodium, uji kadar air dilakukan dengan cara gravimetri, prinsip penentuan kadar serat kasar menggunakan metode gravimetri, uji kadar abu menggunakan prinsip pengabuan secara langsung. Data dari hasil 
pengujian kandungan gizi buah diolah dengan aplikasi SAS versi 6.12 tahun 1996 menggunakan model ANOVA RAL diikuti $L S D \alpha=0,05$.

\section{HASIL DAN PEMBAHASAN}

Tahap uji kandungan gizi, sebelum dilakukan pengujian di Laboratorium, dilakukan pengamatan terhadap sifat fisik buah kancing baju, ketipan, dan tamang hutan (Tabel 1) dan pengamatan tingkat kematangan buah berupa pengukuran terhadap kadar gula dan kadar asam terhadap buah kancing baju, ketipan, dan tamang hutan (Tabel 2).

\begin{tabular}{lccc}
\multicolumn{4}{c}{ Tabel 1 Sifat Fisik Buah Kancing Baju, Ketipan, dan Tamang Hutan } \\
\hline \multicolumn{1}{c}{ Karakteristik } & Kancing Baju & Ketipan & Tamang Hutan \\
\hline Warna kulit muda & Hijau muda & Hijau & Hijau \\
Warna kulit matang & Coklat & Kuning kecoklatan & Merah \\
Permukaan kulit & Berbulu & Kesat & Licin \\
Warna daging & Putih Kehitaman & Putih transparan & Merah \\
Warna biji & Hitam & Jingga kecokelatan & Cokelat \\
Ukuran buah & $1,5 \mathrm{~cm}$ & $3,2 \mathrm{~cm}$ & $0,6 \mathrm{~cm}$ \\
Bentuk buah & Bulat kecil & Bulat seperti duku & Bulat kecil \\
Jumlah biji & - & $3-5$ & 1 \\
Ukuran biji & 0,1 mm & $0,4-1,5 \mathrm{~cm}$ & $0,3 \mathrm{~cm}$ \\
Tekstur daging buah & Agak keras & Lembut berair & Lembut berair \\
Rasa daging buah & Asam pahit & Asam manis & Asam manis \\
Aroma buah & Khas & Bau buah duku & - \\
\hline
\end{tabular}

Berikut buah buah kancing baju, ketipan, dan tamang hutan dalam keadaan utuh dan dikupas. 


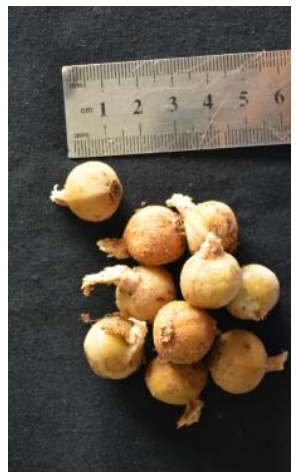

(a)

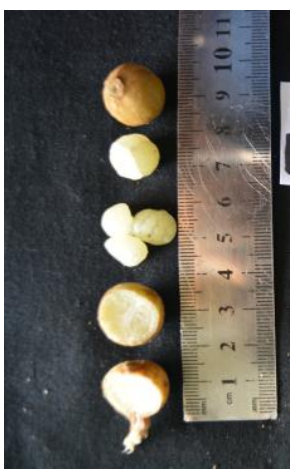

(b)

Gambar 1 Buah Kancing Baju: (a) Utuh, (b) Dikupas

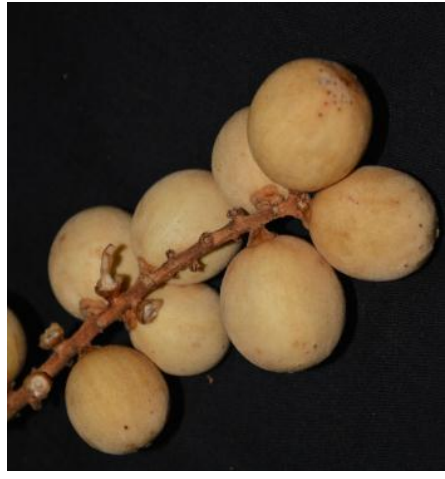

(a)

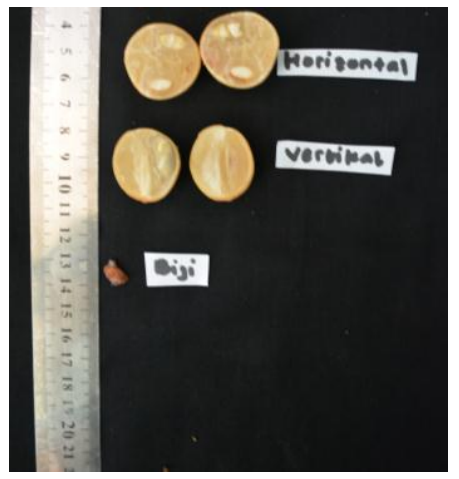

(b)

Gambar 2 Buah Ketipan: (a) Utuh, (b) Dikupas

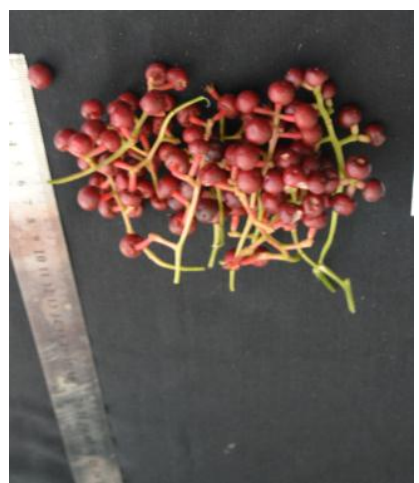

(a)

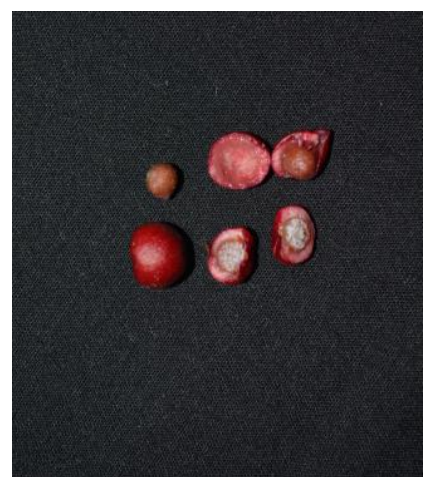

(b)

Gambar 3. Buah Tamang Hutan: (a) Utuh, (b) Dikupas

Buah kancing baju, ketipan, dan tamang hutan memiliki warna kulit saat muda yaitu hijau muda, namun saat matang kulit buah berwarna yang berbedabeda. Pada buah kancing baju warna kulit buah cokelat dan daging buah bewarna putih kehitaman. Buah ketipan warna kulit buah kuning kecokelatan dengan 
daging buah bewarna putih transparan, sedangkan buah tamang hutan warna kulit dan daging buah bewarna merah. Permukaan kulit buah bervariasi yaitu buah kancing baju permukaan kulit buah berbulu, buah ketipan permukaan kulit kasar, dan buah tamang hutan memiliki permukaan kulit yang licin.

Ukuran buah ketipan lebih besar dibanding buah tamang hutan, dan buah kancing baju. Tingkat kekerasan dari buah dapat mempengaruhi sifat fisik pada tekstur dan rasa daging buah, seperti buah kancing baju memiliki tekstur daging buah yang agak keras dengan rasa buah asam pahit, sedangkan buah ketipan dan tamang hutan lembut berair dengan rasa buah asam manis. Pada saat buah matang buah kancing baju memiliki aroma seperti lengkuas karena buah termasuk Zingiberaceae, buah ketipan aromanya seperti buah duku, dan tamang hutan tidak berbau.

\begin{tabular}{lccc}
\multicolumn{4}{c}{ Tabel 2 Kadar Gula serta Kadar Asam Buah Kancing Baju, Ketipan, dan } \\
\multicolumn{1}{c}{ Tamang Hutan } \\
\hline Keterangan & Kancing baju & Ketipan & Tamang Hutan \\
\hline Saat dipetik & 6,0 & 23,3 & 13,6 \\
Total kadar gula ( ${ }^{\circ}$ brix) & 3,2 & 3,3 & 2,3 \\
Total kadar asam & & & \\
\hline Saat akan diuji & 7,6 & 28,0 & 14,3 \\
Total kadar gula ( ${ }^{\circ}$ brix) & 3,6 & 3,6 & 3,0 \\
Total kadar asam & & & \\
\hline
\end{tabular}

Analisis kadar gula buah kancing baju, ketipan, dan tamang hutan terlihat kadar gula pada saat diuji mengalami peningkatan. Hal tersebut dikarenakan adanya proses respirasi sehingga terjadinya pematangan. Menurut Helmiyesi, dkk. (2008) selama aktivitas respirasi berjalan, maka produk akan mengalami proses pematangan dan kemudian diikuti proses pembusukan. Kecepatan respirasi produk tergantung pada temperatur penyimpanan dan ketersediaan oksigen untuk respirasi. Makin banyak oksigen yang digunakan maka makin aktif respirasinya. 
Analisis kadar asam buah kancing baju, ketipan, dan tamang hutan, terlihat kadar asam buah pada saat diuji mengalami penurunan karena terjadinya respirasi pada buah, menyebabkan kadar gula meningkat karena terjadinya proses kematangan. Hal tersebut sesuai dengan penelitian yang dilakukan Purwatiningsih, dkk. (2012) yang menyatakan bahwa masaknya buah atau hasil tanaman kandungan vitamin $\mathrm{C}$ nya akan menurun kecuali pada jeruk, manga, tomat, dan apel. Pada buah-buahan tersebut kandungan Vitamin $\mathrm{C}$ akan meningkat.

Selanjutnya dilakukan uji proksimat yang bertujuan untuk mengetahui kandungan gizi dari buah. Hasil uji tersebut berupa kadar karbohidrat total, glukosa, fruktosa, sukrosa, protein, lemak, air, abu dan vitamin C yang dianalisis untuk melihat ada tidaknya perbedaan kandungan gizi antara 3 spesies buah kancing baju, ketipan, dan tamang hutan. Adapun hasil analisis tersebut disajikan sebagai berikut.

Tabel 3 Hasil Analisis Kandungan Gizi Buah Kancing Baju, Ketipan, dan Tamang Hutan

\begin{tabular}{|c|c|c|c|}
\hline Kandungan Gizi & Kancing Baju & Ketipan & Tamang Hutan \\
\hline Karbohidrat (gr/100gr) & $49,17 \mathrm{a}$ & $10,53 \mathrm{c}$ & $16,51 \mathrm{~b}$ \\
\hline (gr/100gr) & $1,80 \mathrm{c}$ & $10,37 \mathrm{a}$ & $5,25 \mathrm{~b}$ \\
\hline (gr/100gr) & $1,90 \mathrm{c}$ & $11,00 \mathrm{a}$ & $5,56 \mathrm{~b}$ \\
\hline$(\mathrm{gr} / 100 \mathrm{gr})$ & $1,90 \mathrm{c}$ & $10,17 \mathrm{a}$ & $5,14 \mathrm{~b}$ \\
\hline (gr/100gr) & $3,64 \mathrm{a}$ & $3,24 \mathrm{~b}$ & $3,61 \mathrm{a}$ \\
\hline$(\mathrm{gr} / 100 \mathrm{gr})$ & $10,43 \mathrm{a}$ & $1,11 \mathrm{~b}$ & $1,05 \mathrm{~b}$ \\
\hline (gr/100gr) & $32,28 \mathrm{c}$ & 84,06 a & $77,67 \mathrm{~b}$ \\
\hline (gr/100gr) & $5,50 \mathrm{a}$ & $1,04 \mathrm{c}$ & $1,14 \mathrm{~b}$ \\
\hline Serat Kasar (gr/100gr) & $28,36 \mathrm{a}$ & $0,70 \mathrm{c}$ & $13,17 b$ \\
\hline Vitamin C $\quad(\mathrm{mg} / 100 \mathrm{gr})$ & $250,92 \mathrm{~b}$ & $48,88 \mathrm{c}$ & $362,43 \mathrm{a}$ \\
\hline
\end{tabular}


Analisis data hasil uji kandungan gizi pada karbohidrat total menunjukkan adanya perbedaan yang signifikan antara 3 spesies buah kancing baju, ketipan, dan tamang hutan. Kandungan karbohidrat total tertinggi ada pada buah kancing baju yaitu dengan rata-rata 49,17 gram, yang berbeda nyata dengan buah tamang hutan sebesar 16,51 gram, dan karbohidrat total terendah ada pada buah ketipan yaitu 10,53 gram yang berbeda nyata dengan buah kancing baju (Tabel 3). Karbohidrat total didapatkan dari hasil pengurangan (100-protein-air-dan-abu).

Untuk glukosa, fruktosa, dan sukrosa tertinggi ada pada buah ketipan karena kadar gulanya yang tinggi yaitu 28 ('brix) dibanding buah kancing baju dan tamang hutan. Hal tersebut juga berkaitan dengan rasa manis pada buah ketipan. Sesuai dengan pengertian yaitu fruktosa merupakan gula termanis, terdapat dalam madu dan buah-buahan bersama glukosa. Fruktosa dapat terbentuk dari hidrolisis suatu disakarida yang disebut sukrosa dan fruktosa adalah salah satu gula pereduksi (Budiman, 2009).

Serat kasar tertinggi ada pada buah kancing baju karena kandungan karbohidratnya tinggi. Serat adalah bagian yang dapat dimakan dari tanaman atau karbohidrat analog yang resisten terhadap pencernaan dan absorpsi pada usus halus dengan fermentasi lengkap atau partial pada usus besar. Serat makanan tersebut meliputi pati, polisakarida, oligosakarida, lignin, dan bagian tanaman lainnya.

Kandungan lemak yang rendah pada buah dan sayur mempunyai peranan penting dalam mempertahankan tekstur, rasa, aroma berupa trigliserida, sterol, dan kolesterol. Salah satu sifat lemak adalah apabila terkena panas yang terlalu lama dapat mengakibatkan penurunan kadar lemak yang banyak (Prabandari, dkk., 2005). Pada buah ketipan dan tamang hutan kadar lemak yang didapatkan lebih rendah dibandingkan buah kancing baju.

Protein yang terkandung pada buah-buahan rata-rata yaitu sebesar 3,36 gram (Mukri, 1997). Jadi diantara ketiga jenis buah yang sangat baik untuk dikonsumsi karena memiliki kandungan protein yang tinggi adalah buah kancing baju 3,64 gram/100 gram dan buah tamang hutan 3,61 gram/100 gram. 
Kandungan air tertinggi ada pada buah ketipan. Hal tersebut terlihat dari sifat fisik pada daging buahnya yang banyak mengandung air, dengan tekstur daging buah yang lembut dan berair. Kandungan air yang tinggi biasanya diikuti dengan proses pematangan pada buah yang cepat. Murtadha, dkk. (2012) menyatakan bahwa peningkatan kematangan daging buah disebabkan karena meningkatnya kadar air pada daging buah akibat proses respirasi yang memecah pati menjadi gula dan air. Hal tersebut berkaitan pada peningkatan kadar gula buah ketipan pada saat dipetik 23,3 brix $^{\circ}$ sedangkan pada saat diuji kadar air pada buah ketipan mencapai 28 brix $^{\circ}$. Kandungan air yang tinggi pada daging buah dapat dijadikan sebagai indeks kematangan pada buah ketipan.

Analisis data hasil uji abu menunjukan adanya perbedaan yang signifikan antara tiga spesies buah kancing baju, ketipan, dan tamang hutan. Kandungan abu tertinggi ada pada buah kancing baju, dan yang terendah ada pada buah ketipan. Hal tersebut sesuai dengan pendapat Susanto (2009) semakin tinggi kadar air maka kandungan bahan organik semakin rendah karena pasca panen relatif konstan.

Kandungan vitamin $\mathrm{C}$ tertinggi ada pada buah tamang hutan. Hal tersebut sesuai dengan kadar asam buah tamang hutan yang tinggi sehingga berpengaruh pada kadar vitamin $\mathrm{C}$ nya. Rasa asam pada buah disebabkan adanya kandungan vitamin C pada buah. Fitrianingrum, dkk. (2003) menyatakan bahwa keasaman yang tinggi tercermin pada rasa buah yang masam dan hanya sedikit manis walau pada buah yang sudah matang.

Buah ketipan memiliki potensi untuk dibudidayakan karena memiliki rasa manis dan sedikit asam sehingga masyarakat menyukai buah ini. Buah ketipan sudah diperjualbelikan oleh masyarakat setempat. Potensi yang sangat baik dalam kandungan gizi adalah buah kancing baju, karena buah kancing baju kaya akan karbohidrat, protein, lemak, dan serat, hanya saja buah kancing baju memiliki ukuran yang kecil dan memiliki rasa pahit sehingga masyarakat kurang menyukai buah kancing baju. Pada buah tamang hutan beberapa masyarakat setempat menjadikannya tanaman hias karena keberadaannya mulai jarang ditemui. 


\section{SIMPULAN}

Berdasarkan hasil analisis, dapat disimpulkan bahwa: (1) buah kancing baju memiliki aroma dan rasa yang khas seperti tumbuhan Zingiberaceae, dengan tekstur daging agak keras. Buah ketipan memiliki aroma dan tekstur seperti Lansium sehingga rasanya mirip dengan buah duku hanya saja sedikit asam. Buah tamang hutan tidak memiliki aroma tetapi memiliki rasa yang asam manis, dengan tekstur daging lembut berair; (2) Buah kancing baju memiliki kadar karbohirat total, protein, lemak, abu, dan serat kasar lebih tinggi dibandingkan dengan buah ketipan, dan tamang hutan. Buah ketipan memiliki kadar glukosa, fruktosa, sukrosa dan air lebih tinggi dibandingkan buah kancing baju, dan tamang hutan. Buah tamang hutan memiliki kadar vitamin $\mathrm{C}$ yang lebih tinggi dibandingkan buah kancing baju, dan ketipan; dan (3) Berdasarkan sifat fisik buah ketipan memiliki potensi untuk dibudidayakan karena memiliki rasa manis dan sedikit asam sehingga masyarakat menyukainya. Potensi yang sangat baik dalam kandungan gizi adalah buah kancing baju, karena buah kancing baju kaya akan karbohidrat, protein, lemak, dan serat. Pada buah tamang hutan beberapa masyarakat setempat menjadikannya tanaman hias.

\section{UCAPAN TERIMA KASIH}

Penulis mengucapkan terima kasih kepada Tim Payung penelitian buah langka dan dana mandiri; FKIP UNTAN yang telah memberikan dana DIPA untuk payung penelitian; dan Kepala Laboratorium Kimia Fakultas Pertanian Universitas Tanjungpura yang telah memberikan sarana dalam pengujian kandungan gizi.

\section{DAFTAR PUSTAKA}

Beck, M. E. 2011. Ilmu Gizi dan Diet. Yogyakarta: Yayasan Essentia Medica.

Budiman, M. S. 2009. Modul Kuliah Jurusan Kimia. Bandung: Universitas Pendidikan Indonesia.

Fitrianingrum, R., Sugiyarto, \& Susilowati, A. 2013. Anlisis Kandungan Karbohidrat pada Berbagai tingkat Kematangan buah Karika (Carica 
pubescens) di Kejajar dan Sembungan, Dataran Tinggi Dieng, Jawa Tengah. Bioteknologi, 10(1): 11.

Helmiyesi, Hastuti, R. B., \& Prihastanti, E. 2008. Pengaruh Lama Penyimpanan Terhadap Kadar Gula dan Vitamin C pada Buah Jeruk Siam (Citrus nobilis var. microcarpa). Buletin Anantomi dan Fisiologi, 17(2): 36.

Murtadha, A., Julianti, E., \& Suhaidi, I. 2012. Pengaruh Jenis Pemacu Kematangan Terhadap Mutu Buah Pisang Barangan (Musa paradisiaca L.). Ilmu dan Teknologi Pangan, 1(1): 51.

Plummer, D. T. 1971. An Introduction to Practical Biochemistry. New Delhi: Mc. Graw-Hill Publ.

Prabandari, R., Mangalik, A., Achmad, J., \& Agustiana. 2005. Pengaruh Waktu Perebusan dari Dua Jenis Udang yang Berbeda terhadap Kualitas Tepung Limbah Udang Putih (Penaeus indicus) dan Udang Windu (Penaeus monodon). Environ Scieniteae, 1(1): 26.

Purwatiningsih, B., Leksono, A. S., \& Yanuwiadi, B. 2012. Pengaruh Umur Petik dan Lama Penyimpan terhadap Kandungan Vitamin C pada Buah Anggur (vitis vinifera L.). El-Hayah, 2(2) : 67.

Sudarmadji, S., Haryono, B., \& Suhardi. 1997. Prosedur Analisa untuk Bahan Makanan dan Pertanian. Yogyakarta: Liberty.

Susanto, A. 2009. Uji Korelasi Kadar Air, Kadar Abu, dan Bahan Organik pada Jagung di Tingkat Petani, Pedagang Pengumpul, dan Pedagang Besar. Balai Pengujian Mutu Pakan Ternak Direktorat Jenderal Perternakan Departemen Pertanian. 